\title{
Mercury fluxes and pools in three subtropical forested catchments, southwest China
}

\author{
Zhangwei Wang ${ }^{a}$, Xiaoshan Zhang ${ }^{\mathrm{a}, *}$, Jingsong Xiao ${ }^{\mathrm{b}}$, Ci Zhijia ${ }^{\mathrm{a}}$, Pingzhong $\mathrm{Yu}^{\mathrm{c}}$ \\ ${ }^{a}$ Research Center for Eco-Environmental Sciences, Chinese Academy of Sciences, No. 18 Shuangqing Road, Beijing 100085, PR China \\ ${ }^{\mathrm{b}}$ Guizhou Institute of Environmental Science and Designing, Guiyang 550002, PR China \\ ${ }^{\mathrm{c}}$ Institute of Plant and Environment Protection, Beijing Academy of Agricultural and Forestry Science
}

The subtropical forested catchments are important for retention of atmospheric mercury deposition in southwest China.

\section{A R T I C L E I N F O}

Article history:

Received 18 August 2008

Received in revised form

13 November 2008

Accepted 16 November 2008

\section{Keywords:}

Mercury

Input

Output

Pool

Forested catchments

\begin{abstract}
A B S T R A C T
Forested catchments are an important part of the mercury $(\mathrm{Hg})$ cycle and a link between the atmospheric and the aquatic environments. In this study, $\mathrm{Hg}$ input and output fluxes and its retention were investigated at subtropical forested catchments in southwest China. Significantly enhanced atmospheric Hg inputs were observed, and the contribution of litterfall $\mathrm{Hg}$ plays a more important role at these subtropical forested catchments. The ratios of $\mathrm{Hg}$ output fluxes from stream water to total input were $2.5 \%$ and $1.2 \%$ for $L G S$ and TSP, which were markedly lower than those reported from Europe and North America. The current annual input $\mathrm{Hg}$ only accounted for 0.8 and 1.8 per mille to the $\mathrm{Hg}$ stored in the upper $90 \mathrm{~cm}$ of soil in LGS and TSP. These suggest that subtropical forested catchments are important for retention of atmospheric mercury deposition in southwest China.
\end{abstract}

(c) 2008 Elsevier Ltd. All rights reserved.

\section{Introduction}

Mercury is a well known global contaminant and a potent neurotoxin of significant ecological and public health concern. Neither atmospheric $\mathrm{Hg}$ levels nor ambient concentrations of $\mathrm{Hg}$ in water constitute a direct public health risk at the levels of exposure usually found in nature, and the risk to humans and wildlife occurs as $\mathrm{Hg}$ is transported to water and accumulates in the aquatic food chain (Driscoll et al., 2007). The most widespread concern regarding $\mathrm{Hg}$ is human consumption of fish, for instance fish consumption advisories issued in 44 states including more than $53,000 \mathrm{~km}^{2}$ of lakes and 1,230,000 km of rivers in the USA in 2004. Although about $90 \%$ of the $\mathrm{Hg}$ in fish occurs as methylmercury ( $\mathrm{MeHg}$ ), the cycling of total $\mathrm{Hg}$ is of great concern because it is the source of $\mathrm{MeHg}$ from biological methylation of inorganic $\mathrm{Hg}$ in the environment (Boening, 2000).

Large amounts of studies, mostly in Europe and North America, emphasized that forested catchments act as filters between the atmosphere and the hydrosphere (Hultberg et al., 1995; Bishop and Lee, 1997). Long-range atmospheric transport and subsequent deposition of $\mathrm{Hg}$, directly to water and indirectly via deposition to

\footnotetext{
* Corresponding author. Tel./fax: +86 1062849573.

E-mail address: Zhangxsh@rcees.ac.cn (X. Zhang).
}

terrestrial watersheds are the primary sources of $\mathrm{Hg}$ in aquatic ecosystem in remote areas (Fitzgerald et al., 1998; Peterson et al., 2007). Between $5 \%$ and $25 \%$ of atmospheric $\mathrm{Hg}$ deposited to forest watersheds and reached the associated lakes, which contributed approximately a half of $\mathrm{Hg}$ loading to these lakes (Kang et al., 2000; Galloway and Branfireun, 2004). The amount of $\mathrm{Hg}$ and $\mathrm{MeHg}$ transported from stream water varies as a function of the characteristics of the catchments, including soil type, hydrology, climate, land use and human activities (Porvari et al., 2003; Munthe and Hultberg, 2004).

Mercury cycles among the atmosphere, terrestrial and aquatic ecosystems undergo a series of complex chemical and physical processes. In recent decade, most studies have been carried out in the temperate and boreal forested catchments in Europe and North America, and yet significant gaps remain in our knowledge of $\mathrm{Hg}$ fate within subtropical forested catchments and its effects on aquatic ecosystem functions, and almost none of the data is available on the atmospheric $\mathrm{Hg}$ input, output and pool size in subtropical forested catchments especially in those areas with elevated $\mathrm{Hg}$ emission. According to the results by Hylander (2001), anthropogenic emissions of $\mathrm{Hg}$ still increase in China because of coal-use increasing and industrialization. A recent estimation of $696 \pm 307 \mathrm{t} \mathrm{Hg}$ was emitted into the atmosphere from the anthropogenic source in 2003, and emission of $\mathrm{Hg}$ from southwest China was significant (Wu et al., 2006). Elevated levels of $\mathrm{Hg}$ in the 
atmosphere have been shown in several places in China (Wang et al., 2006a, 2007a; Feng et al., 2004). The characteristics of atmospheric mercury deposition and its subsequent cycling in forested catchments have not been previously reported in China. In this study wet-only precipitation (WP), throughfall (TF), litterfall $(L F)$, stream water $(S W)$ and soil profiles were regularly collected to determine $\mathrm{Hg}$ concentrations. The objective was to quantify the atmospheric $\mathrm{Hg}$ input and output fluxes and the retention in forested catchments, and consequently explore the roles of subtropical forested on the $\mathrm{Hg}$ biogeochemistry cycling.

\section{Material and method}

\subsection{Sites description}

Research forested catchments are TieShanPing (TSP), LuChongGuan (LCG) and LeiGongShan (LGS) in southwest China, which belong to typical subtropical monsoonal climate. TSP and LCG are located near big cities of Chongqing and Guiyang, respectively. Whereas LGS stands in a national forest park away $140 \mathrm{~km}$ of Guiyang, and is more regionally representative and a rural reference site. Mountains surrounding Guiyang and Chongqing cities cause poor air circulation and thus severe air pollution problems. These two areas belong to acid-rain control zone and the largest $\mathrm{Hg}$-producing districts in China. The detailed characteristics about three forested catchments are showed in Table 1.

\subsection{Field sampling}

At each catchment, a modified automated wet-only precipitation collector (SYC-2, QingdaoLaoshan Ltd.) with Teflon-coated funnel connecting to 5-L polyethylene terephthalate (PET) bottle was set up at open space area close-by the catchment. Two $30 \mathrm{~m} \times 30 \mathrm{~m}$ monitoring plots were established in each catchment, and four sets of throughfall samplers were fixed under the canopy of trees at the corners of the plots. The throughfall samplers were self-constructed based on the NILU (Norwegian Institute for Air Research) design, consisting of a 10.6- $\mathrm{cm}$ diameter PET funnel connected to a 3-L PET bottle. Four nylon nets ( $1 \mathrm{~m}^{2}$ each) mounted $1 \mathrm{~m}$ above the forest floor at corners of the plot, were used for litterfall collection. Stream water was collected in the dam at the Vnotch weir at the outlet of forested catchments. Soils were collected at intervals of $10 \mathrm{~cm}$ in typical soil profiles $(0-90 \mathrm{~cm})$ at each catchment.

The wet-only precipitation (WP), throughfall $(T F)$ and stream water $(S W)$ samples were collected weekly and litterfall $(L F)$ monthly. The collecting bottles were pre-acidified with $7.5 \mathrm{ml}$ of $6 \mathrm{~N} \mathrm{HCl}$ (MOS, Suprapur) at the beginning of sampling to avoid the losses of $\mathrm{Hg}$ for volatilization or absorption on the container walls
(Guentzel et al., 1995; Krabbenhoft et al., 1995). All water samples were preserved by $2 \%(\mathrm{v} / \mathrm{v}) \mathrm{HCl}$ to stabilize mercury, and freezing stored in the dark and analyzed for two months. Soil and litterfall samples were natural dried, ground and sieved to $2 \mathrm{~mm}$ for analysis.

\subsection{Laboratory analysis}

To measure $\mathrm{Hg}$ concentrations in water samples, liquid samples were oxidized with $0.2 \mathrm{~N}$ bromine monochloride $(\mathrm{BrCl})$ for at least $12 \mathrm{~h}$. Excess $\mathrm{BrCl}$ was removed by the addition of hydroxylamine hydrochloride $\left(\mathrm{NH}_{2} \mathrm{OH}-\mathrm{HCl}\right)$ prior to analysis. An oxidized sample aliquot was added to bubbler, and $\mathrm{Hg}^{2+}$ in sample was reduced to $\mathrm{Hg}^{0}$ by stannous chloride $\left(\mathrm{SnCl}_{2}\right)$. Then $\mathrm{Hg}^{0}$ was carried and measured in the multi-path analytical cell of RA-915+ analyzer (Lumex Scientific-production Company, Analytical Equipment, St. Petersburg, Russia), which is based on Zeeman atomic absorption spectrometry with high frequency modulation of light polarization (ZAASHFM). The detection limit of this method (defined as $3 \sigma$ of the method blank value) was $0.40 \mathrm{ng} \mathrm{L}^{-1}$ for $20 \mathrm{ml}$ aliquot.

$\mathrm{Hg}$ concentrations in soil and $L F$ samples were determined by RA-915+ analyzer attached with PYRO-91 thermal decomposition accessory from Lumex Ltd. The solid samples were directly decomposed in atomizer chamber at $800{ }^{\circ} \mathrm{C}$ with the aided catalytic action, and then $\mathrm{Hg}^{0}$ was detected by the $\mathrm{RA}-915+$ analyzer. Detection limits were $0.5 \mu \mathrm{g} \mathrm{kg}^{-1}$ for soil and $0.5 \mu \mathrm{g} \mathrm{kg}{ }^{-1}$ for litterfall samples. The detailed information was documented by Chen et al. (2001), USEPA (2004) and Huang et al. (2006).

\subsection{Validation of analytical and sampling methods}

Application RA-915+ analyzer with a multi-path analytical cell attached the RP-91 (cold vapor) and PYRO-91 (pyrolysis) accessories allow to analyze $\mathrm{Hg}$ in liquid and solid samples, and some authors have successfully used these methods for measuring $\mathrm{Hg}$ concentrations in water (Esbrí and Higueras, 2005; Higuerasa et al., 2006; Won et al., 2007) and solid (Chen et al., 2001; Oyarzun et al., 2007; Rodriguez et al., 2007; Shuvaeva et al., 2008) samples. In this study, the precision, obtained from eight replicate determinations of certificated reference material, was $3.0 \%$ for diluted $\left(10 \mathrm{ng} \mathrm{L}^{-1}\right.$ ) $\mathrm{Hg}$ standard solution (GBW08617), 2.1\% for soil (GBW07404) and $3.3 \%$ for peach leave (GBW08501). The recoveries were ranged between $92.2 \%$ and $105.1 \%$ for water samples, and from $96.0 \%$ to $102.3 \%$ for solid materials. In addition, calibration curves covering the appropriate concentration levels were run each day during analysis and control standard sample checked every tenth sample.

In this study, all containers for sampling and storage were made of polyethylene terephthalate (PET). Documents have validated that

Table 1

Characteristics of three research forested catchments.

\begin{tabular}{|c|c|c|c|}
\hline Site & TSP (TieShanPing) & LGS (LeiGongShan) & LCG (LuChongGuan) \\
\hline Latitude and longitude & $104^{\circ} 41^{\prime} \mathrm{E}, 29^{\circ} 38^{\prime} \mathrm{N}$ & $108^{\circ} 11^{\prime} \mathrm{E}, 26^{\circ} 22^{\prime} \mathrm{N}$ & $106^{\circ} 43^{\prime} \mathrm{E}, 26^{\circ} 38^{\prime} \mathrm{N}$ \\
\hline Elevation (a.s.l., m) & $450-500$ & $1630-1735$ & $1320-1400$ \\
\hline Catchment area (ha) & 16.3 & 6.0 & 7.0 \\
\hline $\begin{array}{l}\text { Annual mean } \\
\text { temperature }\left({ }^{\circ} \mathrm{C}\right)^{\mathrm{a}}\end{array}$ & 18.2 & 15.7 & 15.3 \\
\hline Annual precipitation $(\mathrm{mm})^{\mathrm{b}}$ & 1230 & 1615 & 1120 \\
\hline Mean daily RH (\%) & 95 & 92 & 82 \\
\hline Soil classification & Haplic acrisol/alisol & Haplic acrisol/alisol & Haplic acrisol/alisol \\
\hline Bed rock & Sandstone & Shale & Sandstone \\
\hline $\begin{array}{l}\text { Vegetation information } \\
\text { and ecosystem type }\end{array}$ & $\begin{array}{l}\text { Massone Pine dominated, } \\
\text { coniferous-broad leave } \\
\text { mixed subtropical forest }\end{array}$ & $\begin{array}{l}\text { Pinus armandii } \\
\text { dominated, coniferous-broad } \\
\text { leave mixed subtropical forest }\end{array}$ & $\begin{array}{l}\text { Massone pine and Cunning-hamia } \\
\text { lanceolata dominated, broad leave-coniferous } \\
\text { mixed subtropical forest }\end{array}$ \\
\hline
\end{tabular}

\footnotetext{
${ }^{a, b, c}$ Data from nearby meteorological stations.
} 
Table 2

$\mathrm{Hg}$ concentrations in wet-only precipitation and throughfall.

\begin{tabular}{|c|c|c|c|c|c|c|c|}
\hline \multirow[t]{2}{*}{ Site } & \multirow[t]{2}{*}{ Types } & \multirow[t]{2}{*}{ Rainfall (mm) } & \multicolumn{5}{|c|}{ Concentration of $\mathrm{Hg}\left(\mathrm{ng}^{\circ} \mathrm{L}^{-1}\right)$} \\
\hline & & & Mean & Median & Minimum & Maximum & V.W.C. ${ }^{\mathrm{a}}$ \\
\hline \multirow[t]{2}{*}{ LGS } & WP & 1341 & 19.5 & 14.9 & 3.5 & 71.0 & 12.9 \\
\hline & $\mathrm{TF}$ & 938 & 54.2 & 40.2 & 8.1 & 285.9 & 36.7 \\
\hline \multirow[t]{2}{*}{ TSP } & WP & 1403 & 55.3 & 39.0 & 9.1 & 232.7 & 32.3 \\
\hline & $\mathrm{TF}$ & 1145 & 98.9 & 74.4 & 11.7 & 582.9 & 69.7 \\
\hline$L C G^{\mathrm{b}}$ & $\mathrm{TF}$ & 929 & 83.6 & 47.5 & 3.5 & 493.3 & 43.6 \\
\hline
\end{tabular}

a V.W.C. - annual volume-weighted mean concentration.

b No WP samples were collected at LCG catchment due to the absence of equipment.

the PET containers are fit for sampling and storage of natural water for Hg analysis (Copeland et al., 1996; Fatemian et al., 1999; Fadini and Jardim, 2000), and more and more studies performed based on it (Paraquetti et al., 2004; Silva et al., 2006; Wang et al., 2005). In our laboratory, no significant difference was found for the storage samples in Teflon and PET bottles (Paired $t$-test, $p=0.028$ ) for three months. The procedures of field blanks for $W P$ and $T F$ were referred to the description of Guentzel et al. (1995) and Glass and Sorensen (1999). The reagents for preserving and analyzing of samples were of ultra pure quality grade.

\section{Results and discussions}

\subsection{Wet-only precipitation and throughfall}

$\mathrm{Hg}$ concentrations in WP and TF are presented in Table $2 . \mathrm{Hg}$ annual volume-weighted mean concentrations in $T F$ were $69.7 \mathrm{ng} \mathrm{L^{-1 }}, 36.7 \mathrm{ng} \mathrm{L}^{-1}$ and $43.6 \mathrm{ng} \mathrm{L}^{-1}$ for TSP, LGS and LCG respectively, which were about two times higher than those in WP during this study and approximately three times higher than those in $T F$ reported from temperate and boreal forested catchments in
Europe and North America (Rea et al., 2000; St. Louis et al., 2001; Larssen et al., 2008). Hg concentrations in deposition decreased in the order of TSP $>$ LCG $>L C G>L G S$ with significant difference among the sites (Kruskal-Wallis test, $P_{T F}=0.0001$ ). This is because that LGS is located in a remote area relatively isolated from industrial and human activities, while other two sites are located in suburban areas and are more strongly interfered by anthropogenic activities.

Fig. 1 shows weekly and seasonal $\mathrm{Hg}$ deposition fluxes from $W P$ and $T F$ during the campaign. The mean weekly fluxes of WP were $0.43 \pm 0.40 \mu \mathrm{g} \mathrm{m}^{-2}$ week $^{-1}$ and $1.29 \pm 0.50 \mu \mathrm{g} \mathrm{m}^{-2}$ week $^{-1}$ at $L G S$ and TSP, and $0.89 \pm 0.60 \mu \mathrm{g} \mathrm{m}^{-2}$ week $^{-1}, 2.69 \pm 0.92 \mu \mathrm{g} \mathrm{m}^{-2}$ week $^{-1}$ and $0.98 \pm 0.68 \mu \mathrm{g} \mathrm{m}^{-2}$ week $^{-1}$ for TF at LGS, TSP and LCG, respectively. Compared with the values in $W P$, the elevated $\mathrm{Hg}$ fluxes from TF implied that the forest canopy is important for increasing $\mathrm{Hg}$ input to the forest floor, most likely due to atmospheric scavenging. $\mathrm{Hg}$ fluxes from TF were slightly higher in spring than other seasons at these catchments, which may be due to wash-off dry deposition of $\mathrm{Hg}$ that accumulated on the forest canopy in the dry winter season. The ratios of weekly Hg input fluxes via $T F$ to those from WP were 3.0 for LGS and 3.2 for TSP, which were greater than the value of
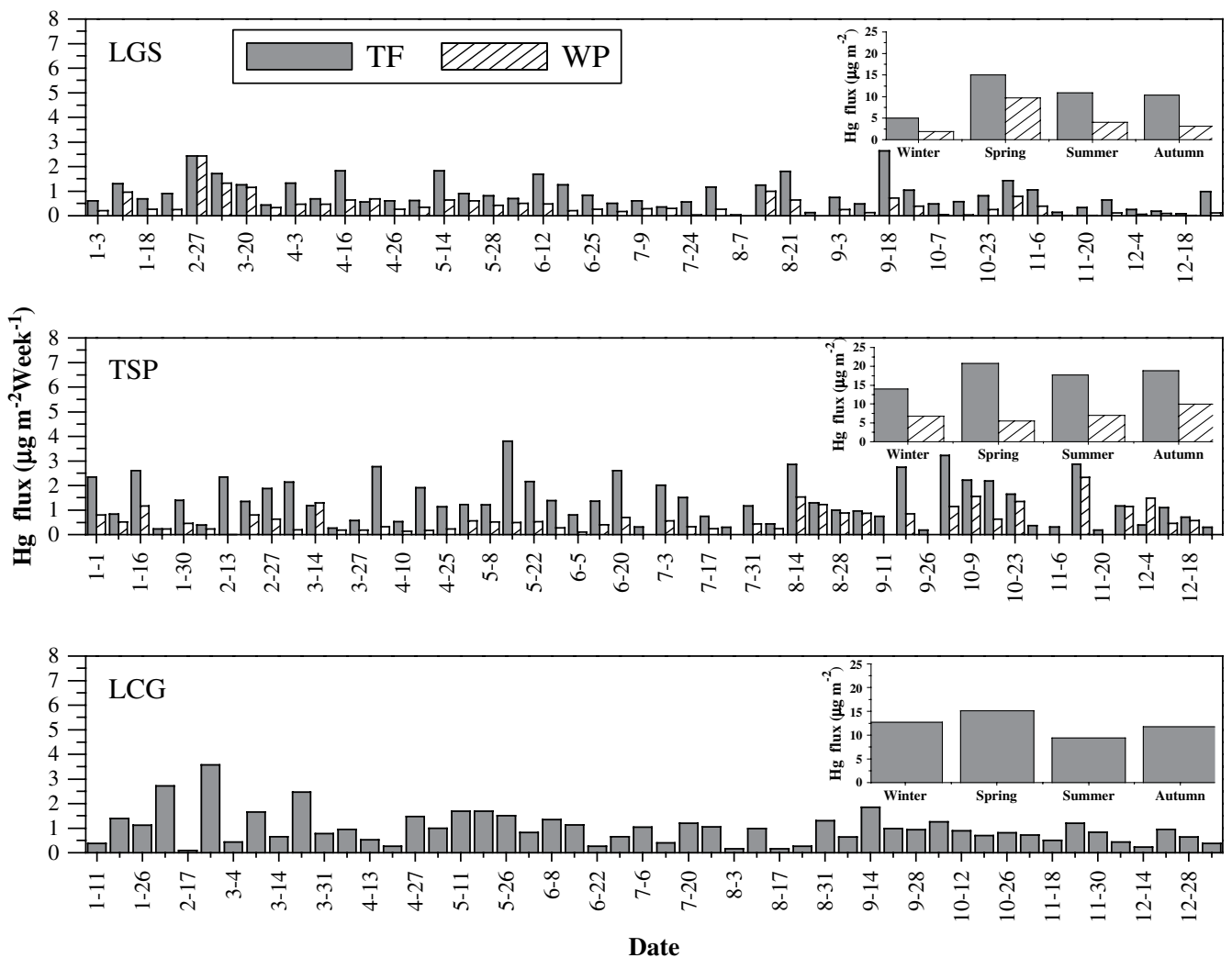

Fig. 1. Weekly Hg deposition fluxes from wet-only precipitation and throughfall. 

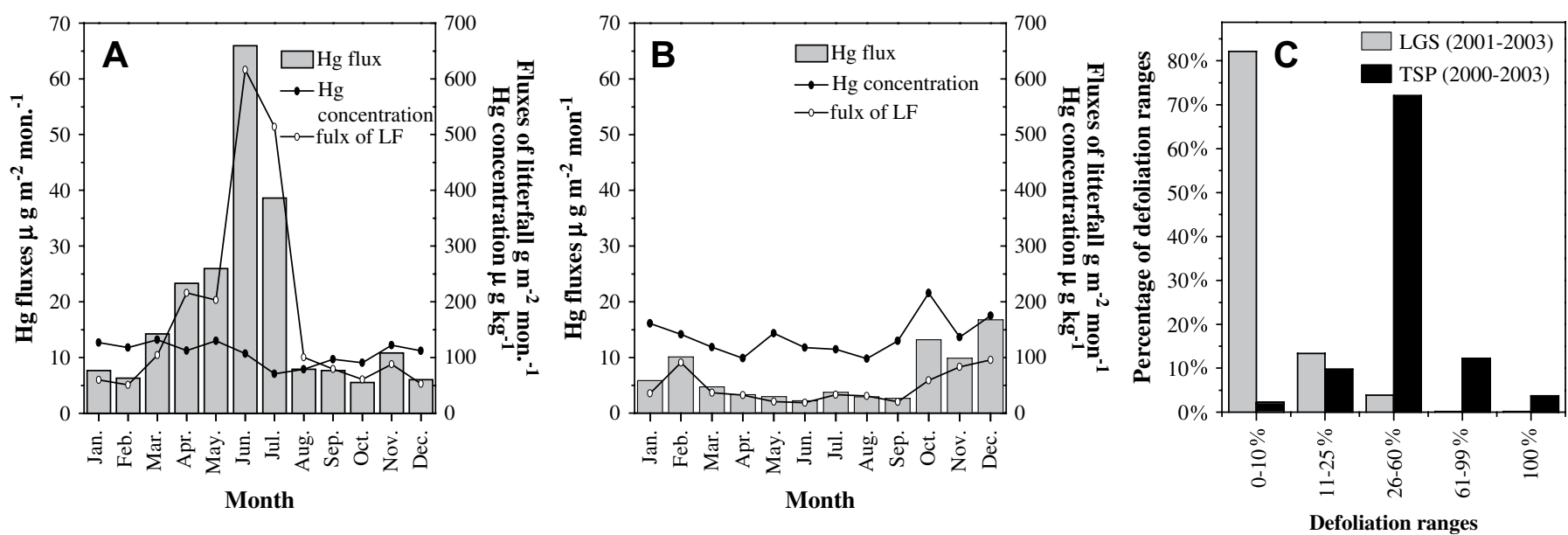

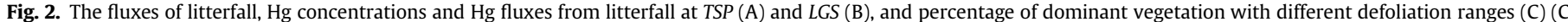
data from IMPACTS, 2004).

1.5 suggested by Munthe et al. (1995) and also higher than the overall mean ratio of 1.8 for temperate and boreal forest reviewed by Grigal (2002). This is in accordance with deposition of main compounds (e.g. sulphur and calcium) in these catchments, where also the fraction of dry deposition relative to wet is higher than typical values in Europe and North America (Larssen et al., 2006). This indicated that the dry deposition of atmospheric $\mathrm{Hg}$ plays more significant role for the mercury cycling in these subtropical forested catchments.

\subsection{Litterfall}

$\mathrm{Hg}$ average concentrations in $L F$ were $135.1 \pm 31.7 \mu \mathrm{g} \mathrm{kg}^{-1}$ for LGS and $104.8 \pm 18.6 \mu \mathrm{g} \mathrm{kg}^{-1}$ for TSP, which were higher than those in conifer and hardwood at temperate and boreal forest (Lindberg,
1996; St. Louis et al., 2001; Larssen et al., 2008) but much lower than the levels $\left(10^{5}-10^{6} \mu \mathrm{g} \mathrm{kg}{ }^{-1}\right)$ in seriously pollutant areas (Siegel et al., 1984; Fischer et al., 1995). The monthly Hg input fluxes from $L F$ at $\operatorname{TSP}\left(18.4 \pm 18.1 \mu \mathrm{g} \mathrm{m}^{-2} \mathrm{mon}^{-1}\right)$ were much higher than that at LGS $\left(6.5 \pm 4.8 \mu \mathrm{g} \mathrm{m}^{-2} \mathrm{mon}^{-1}\right)$, even if lower $\mathrm{Hg}$ contents were found in $L F$ at TSP. From Fig. $2 \mathrm{~A}$ and B, the seasonal variation of $\mathrm{Hg}$ fluxes via $L F$ was contrary, and high $\mathrm{Hg}$ fluxes occurred in spring and summer at TSP and yet in autumn and winter at LGS. These were attributed to the large difference of the fluxes from litterfall input between two sites, and seventy two percent of litterfall deposited to the floor during March to July at TSP. Furthermore, from Fig. 2C, the three years (2001-2003) mean defoliation percentage was $45 \%$ at TSP and $3 \%$ at LGS, and a recent study showed that the pressure of air pollution and defoliating insects play major roles for forest damage at TSP (Wang et al., 2007b). As

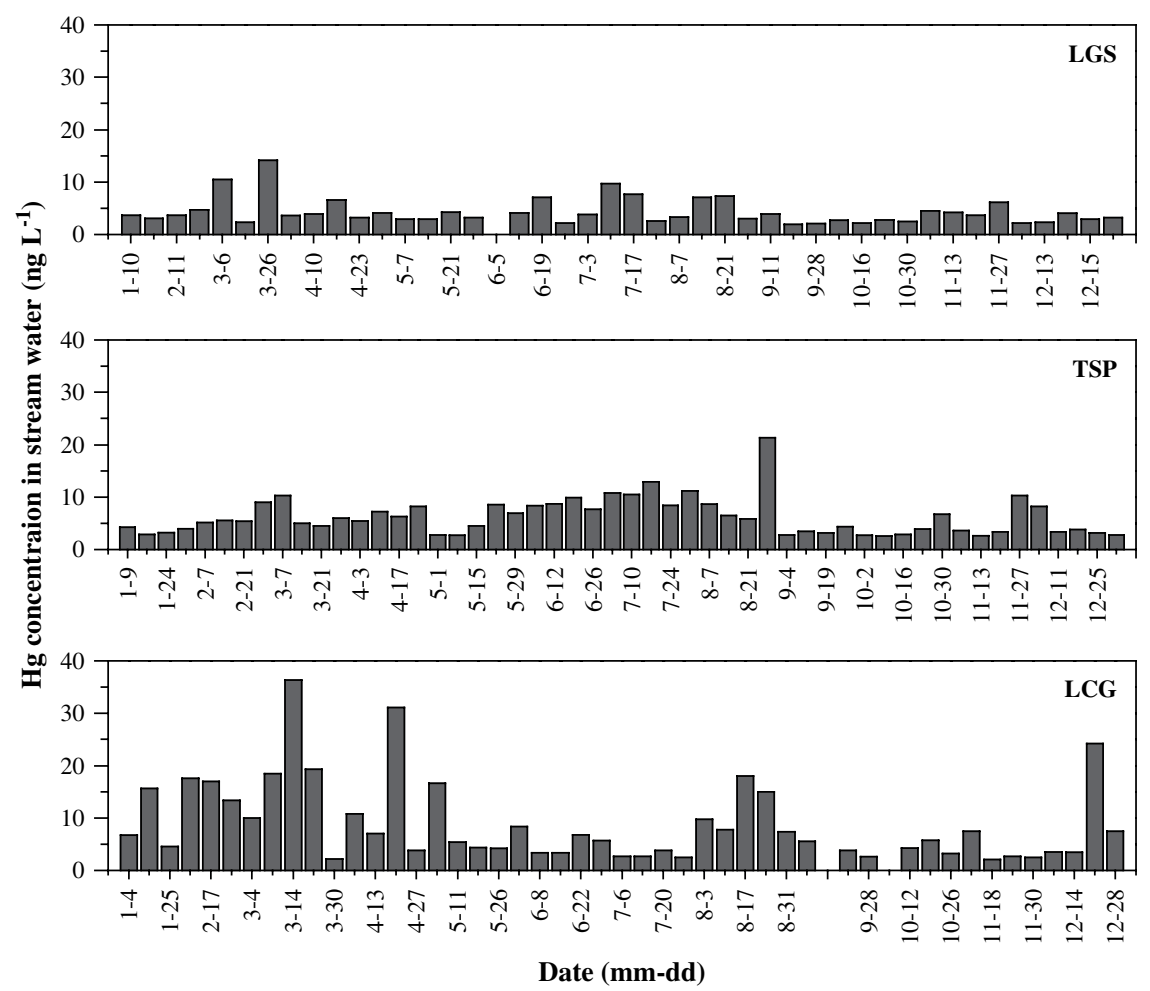

Fig. 3. Mercury concentrations in stream water from forested catchments. 


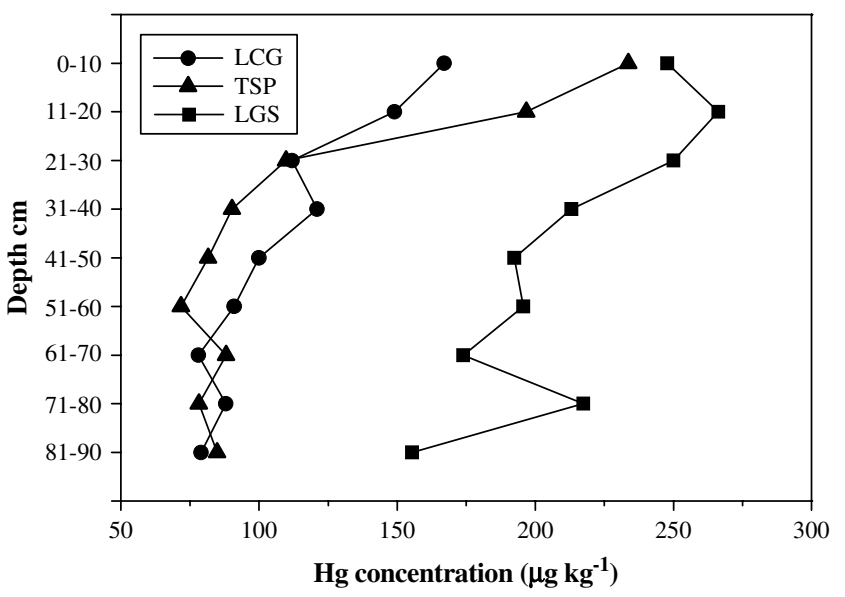

Fig. 4. Hg distribution in soil profile at three catchments.

thus elevated $\mathrm{Hg}$ concentrations in litterfall at LGS may be the consequence of long growing seasons for foliage to uptake $\mathrm{Hg}$ from atmosphere. Several studies have indicated that $\mathrm{Hg}$ concentrations in foliage increase with the growing season (Fleck et al., 1999; Rea et al., 2001).

\subsection{Stream water}

At the three forested catchments, $\mathrm{Hg}$ concentrations in stream water ranged from $1.9 \mathrm{ng} \mathrm{L^{-1 }}$ to $36.3 \mathrm{ng} \mathrm{L}^{-1}$ and the mean concentration was $4.3 \pm 2.5 \mathrm{ng} \mathrm{L}^{-1}$ for $L G S, 6.2 \pm 3.5 \mathrm{ng} \mathrm{L}^{-1}$ for TSP and $8.9 \pm 6.7 \mathrm{ng} \mathrm{L}^{-1}$ for $L C G$ (Fig. 3), which were comparable to those from temperate and boreal forested catchments. Significant difference of $\mathrm{Hg}$ concentrations in stream water was found among these sites (Kruskal-Wallis test, $P=0.0003$ ), which may be attributed to the characteristics of catchments and the disturbance of anthropogenic activities such as deforestation and disarrange soil. LCG locates in a botanical garden of the Guiyang suburban and cutting and trample disturbances occurred frequently, and yet LGS stands at a remote and natural forest area. Fostier et al. (2000) discovered that $\mathrm{Hg}$ concentrations in stream water from natural forest areas (2.5 $\mathrm{ng} \mathrm{L}^{-1}$ ) were much lower than those (8.9 $\mathrm{ng} \mathrm{L}^{-1}$ ) from disturbed forest areas.

The annual output fluxes of $\mathrm{Hg}$ from stream water were $3.0 \mu \mathrm{g} \mathrm{m}^{-2} \mathrm{a}^{-1}$ for LGS, $3.5 \mu \mathrm{g} \mathrm{m}^{-2} \mathrm{a}^{-1}$ for TSP and $4.5 \mu \mathrm{g} \mathrm{m}^{-2} \mathrm{a}^{-1}$ for $L C G$, which were calculated using the weekly $\mathrm{Hg}$ concentration and the estimated discharge of stream water. In this study, the water fluxes of stream water were calculated using $70 \%$ of the actual throughfall in LGS and 50\% in TSP and LCG, which were based on the results of four years (2001-2004) monitoring of IMPACTS (Larssen et al., 2006) and referred to the report of Fujieda et al. (1997) and Wei et al. (2005). In addition, no statistically significant correlations were discovered between $\mathrm{Hg}$ in stream water and $\mathrm{Hg}$ input from $W P$ and TF during study period, implying that $\mathrm{Hg}$ output from stream water is regulated by processes other than current deposition input in these subtropical forested catchments.

\subsection{Catchments pools}

At these forested catchments, $\mathrm{Hg}$ contents in soils at LGS were much higher than other two sites (Fig. 4). Hg contents in soils decreased with the increase of soil depth at three catchments, and the highest surface contents were $259 \mu \mathrm{g} \mathrm{kg}^{-1}, 239 \mu \mathrm{g} \mathrm{kg}{ }^{-1}$ and $167 \mu \mathrm{g} \mathrm{kg}^{-1}$ for LGS, TSP and LCG, respectively. Furthermore, soil water was aperiodically sampled using lysimeter at TSP during study period, and $\mathrm{Hg}$ concentrations in soil water were much higher at $2 \mathrm{~cm}$ depth $\left(59.6 \pm 40.3 \mathrm{ng} \mathrm{L}^{-1}\right)$ than those at $20 \mathrm{~cm}$ depth $\left(10.1 \pm 7.9 \mathrm{ng} \mathrm{L}^{-1}\right)$, indicating that $\mathrm{Hg}$ from atmospheric deposition was main retention in upper layer soil in forested catchments. The storage of $\mathrm{Hg}$ in soil (0-90 cm depth), estimated through the soil bulk density of corresponding horizon (IMPACTS, 2004) and $\mathrm{Hg}$ contents in each soil profile, was $1523 \mathrm{~g} \mathrm{ha}^{-1}$ for LGS, $1647 \mathrm{~g} \mathrm{ha}^{-1}$ for TSP and $938 \mathrm{~g} \mathrm{ha}^{-1}$ for $L C G$.

\subsection{Catchments budgets}

The annual budgets of $\mathrm{Hg}$ at these catchments are presented in Fig. 5. Total input of $\mathrm{Hg}$, the sum flux of TFand $L F$, was $119.5 \mu \mathrm{g} \mathrm{m}^{-2} \mathrm{a}^{-1}$ for LGS and $291.2 \mu \mathrm{g} \mathrm{m}^{-2} \mathrm{a}^{-1}$ for TSP, which was much higher than those from temperate and boreal forest catchments (Schwesig and Matzner, 2000; Lee et al., 2000; Munthe et al., 1998; St. Louis
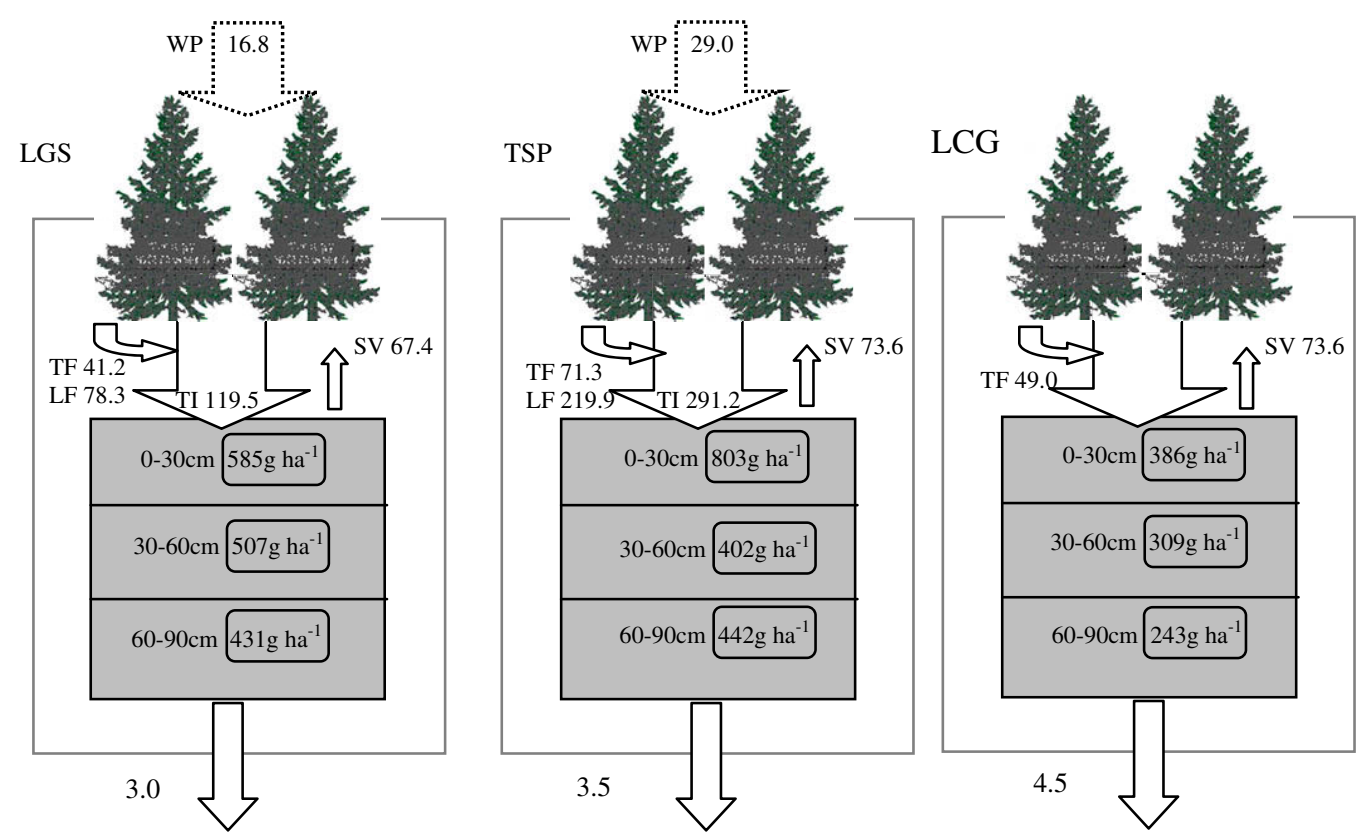

Fig. 5. Hg budgets for three forested catchments (units: $\mu \mathrm{g} \mathrm{m}^{-2} \mathrm{a}^{-1}$, SV represents soil volatilization and TI shows total input). 
Table 3

The comparison of $\mathrm{Hg}$ input/output in this study with other reported.

\begin{tabular}{|c|c|c|c|c|c|c|c|c|c|c|c|}
\hline \multirow[t]{2}{*}{ Site } & \multirow[t]{2}{*}{ Location } & \multirow[t]{2}{*}{ Forest type } & \multirow[t]{2}{*}{ Period } & \multicolumn{2}{|c|}{ Input } & \multirow[t]{2}{*}{ Output SW } & \multirow{2}{*}{$\begin{array}{l}\text { Soil storage } \\
\left(\mathrm{g}^{\circ} \mathrm{ha}^{-1}\right)\end{array}$} & \multirow{2}{*}{$\begin{array}{l}\text { LF/input } \\
(\%)\end{array}$} & \multirow{2}{*}{$\begin{array}{l}\text { Input/ } \\
\text { storage (\%) }\end{array}$} & \multirow{2}{*}{$\begin{array}{l}\text { SW/input } \\
(\%)\end{array}$} & \multirow[t]{2}{*}{ Ref. } \\
\hline & & & & $\mathrm{TF}^{\mathrm{a}}$ & $\mathrm{LF}^{\mathrm{a}}$ & & & & & & \\
\hline$\overline{L G S}$ & $108^{\circ} 11^{\prime} \mathrm{E}$ & Pinus armandii & $2005 / 3-2006 / 2$ & 41.2 & 78.3 & 3 & $1092^{b}$ & 65.5 & $0.11^{\mathrm{b}}$ & 2.5 & This study \\
\hline Southwest China & $26^{\circ} 22^{\prime} \mathrm{N}$ & & & & & & $1523^{c}$ & & $0.08^{c}$ & & \\
\hline TSP & $104^{\circ} 41^{\prime} \mathrm{E}$ & Masson pine & $2005 / 3-2006 / 3$ & 71.3 & 219.9 & 3.5 & $1205^{b}$ & 75.5 & $0.24^{\mathrm{b}}$ & 1.2 & \\
\hline Southwest China & $29^{\circ} 38^{\prime} \mathrm{N}$ & & & & & & $1647^{c}$ & & $0.18^{\mathrm{c}}$ & & \\
\hline LCG & $106^{\circ} 43^{\prime} \mathrm{E}$ & Massone pine & $2005 / 1-2006 / 1$ & 49.0 & & 4.5 & $695^{b}$ & - & - & - & \\
\hline Southwest China & $26^{\circ} 38^{\prime} \mathrm{N}$ & & & & & & $938^{c}$ & & & & \\
\hline Lehstenbach & $11^{\circ} 52^{\prime} \mathrm{E}$ & Norway spruce & 1998/4-1999/4 & 38.4 & 15.7 & 7 & 891 & 29 & 0.06 & 13 & Schwesig \\
\hline Germany & $50^{\circ} 08^{\prime} \mathrm{N}$ & & & & & & $(0-60 \mathrm{~cm})$ & & & & and Matzner, 2000 \\
\hline Steinkreuz & $10^{\circ} 27^{\prime} \mathrm{E}$ & Fagus sylvatica L. & 1998/4-1999/4 & 27.8 & 34 & 2.8 & 193 & 55 & 0.32 & 4.5 & \\
\hline Germany & $49^{\circ} 52^{\prime} \mathrm{N}$ & & & & & & $(0-60 \mathrm{~cm})$ & & & & \\
\hline Svartberget & $19^{\circ} 46^{\prime} \mathrm{E}$ & Norway spruce & 1993-1998 & 15 & 18 & 1.6 & - & 54.5 & - & 4.8 & Lee et al., 2000 \\
\hline Sweden & $64^{\circ} 14^{\prime} \mathrm{N}$ & & & & & & & & & & \\
\hline Gårdsjön & $12^{\circ} 03^{\prime} \mathrm{E}$ & Norway spruce & 1995-1997 & 23 & 23 & 1.8 & 280 & 50 & 0.16 & 3.9 & Munthe et al., 1998 \\
\hline Sweden & $58^{\circ} 04^{\prime} \mathrm{N}$ & & & & & & $(0-60 \mathrm{~cm})$ & & & & \\
\hline Marcell & $93^{\circ} 28 \mathrm{~W}$ & Black spruce & $1995 / 4-11$ & 13 & 12.3 & 2.81 & 48 & 48.6 & 0.53 & 11 & Grigal et al., 2000 \\
\hline Minnesota & $47^{\circ} 32^{\prime} \mathrm{N}$ & Aspen & & & & & $(0-50 \mathrm{~cm})$ & & & & \\
\hline ELA, Ontario & $\begin{array}{l}93^{\circ} 43^{\prime} \mathrm{W} \\
49^{\circ} 40^{\prime} \mathrm{N}\end{array}$ & $\begin{array}{l}\text { Tamarack and } \\
\text { black spruce }\end{array}$ & 1998-1999 & 8 & 12 & & & 60 & & & St. Louis et al., 2001 \\
\hline Lake Huron & $\begin{array}{l}84^{\circ} 48^{\prime} \mathrm{W} \\
45^{\circ} 34^{\prime} \mathrm{N}\end{array}$ & Maple and beech & 1996/6-1997/6 & 10.5 & 11.4 & & & 52.1 & & & $\begin{array}{l}\text { Rea and Lindberg, } \\
2001\end{array}$ \\
\hline Hadlock Brook & $44^{\circ} 20^{\prime} \mathrm{W}$ & Maple and & 1999-2004 & 10.2 & 10.1 & 2.46 & & 49.8 & & 12.1 & Johnson and \\
\hline Cadillac Brook & $68^{\circ} 13^{\prime} \mathrm{N}$ & paper birch & & 9.4 & 10 & 0.76 & & 51.5 & & 3.9 & $\begin{array}{l}\text { Haines, 2007; } \\
\text { Sheehan and Fernandez, } \\
\text { 2006; Nelson and } \\
\text { Johnson, } 2007\end{array}$ \\
\hline $\begin{array}{l}\text { Langtjern } \\
\text { Sutheast Norway }\end{array}$ & $\begin{array}{l}9^{\circ} 39^{\prime} \mathrm{E} \\
60^{\circ} 22^{\prime} \mathrm{N}\end{array}$ & Scots pine & $2004 / 2005$ & 6.7 & 2.7 & 2.5 & $\begin{array}{c}174 \\
(\mathrm{O}-\mathrm{B})\end{array}$ & 28.7 & 0.05 & 26.6 & Larssen et al., 2008 \\
\hline Review & $\begin{array}{l}\text { Temperate } \\
\text { boreal zon }\end{array}$ & $\begin{array}{l}\text { and } \\
\text { les }\end{array}$ & 1990-2000 & 17 & 21 & 1.7 & & 55.5 & & 4.5 & Grigal, 2002 \\
\hline
\end{tabular}

a The unit of input and output fluxes was $\mu \mathrm{g} \mathrm{m}^{-2} \mathrm{a}^{-1}$.

$\mathrm{b}, \mathrm{c}$ Represent the soil of $0-60 \mathrm{~cm}$ and $0-90 \mathrm{~cm}$, respectively.

et al., 2001; Grigal, 2002; Johnson and Haines, 2007). This implied that enhanced atmospheric $\mathrm{Hg}$ deposition exists in forest catchments at southwest China, and it may be attributed to the elevated $\mathrm{Hg}$ emission from coal combustion and mining. In this study, $\mathrm{Hg}$ volatilization fluxes from forest floor were estimated through the $\mathrm{Hg}$ release velocity measured by Wang et al. (2006b) using dynamic flux chamber from forest soils surface at remote and suburban sites in Chongqing of southwest China. And we also referred the emission fluxes of $\mathrm{Hg}$ from soil in Guiyang (Feng et al., 2003) and from forest floor of the Adirondacks in New York (Choi and Holsen, 2009). The estimated fluxes of $\mathrm{Hg}$ volatilization were $67.4 \mu \mathrm{g} \mathrm{m}^{-2} \mathrm{a}^{-1}$ for LGS and $73.6 \mu \mathrm{g} \mathrm{m}^{-2} \mathrm{a}^{-1}$ for TSP and LCG. Therefore the annual net retention $\mathrm{Hg}$ from the atmosphere was $49.1 \mu \mathrm{g} \mathrm{m}^{-2} \mathrm{a}^{-1}$ for LGS and $214.1 \mu \mathrm{g} \mathrm{m}^{-2} \mathrm{a}^{-1}$ for TSP, which only accounted for about $0.03 \%$ and $0.13 \%$ of the soil $(0-90 \mathrm{~cm})$ storage $\mathrm{Hg}$ in $L G S$ and TSP, respectively.

\subsection{The role of forested catchments in mercury cycling in China}

A comparison of $\mathrm{Hg}$ input/output in subtropical forested catchments with those in temperate and boreal forested catchments is shown in Table 3. The input fluxes of $\mathrm{Hg}$ via $L F$ accounted for $65.5 \%$ and $75.5 \%$ of total input at LGS and TSP, respectively, which were significantly higher than those from temperate and boreal forested catchments, suggesting that $\mathrm{Hg}$ input via litterfall may play a more important role to the mercury cycling in subtropical forested catchments. The output fluxes of $\mathrm{Hg}$ from stream water in this study were comparable with those in temperate and boreal forested catchments, but inputs considerably higher and hence the ratios of $\mathrm{Hg}$ output to total input in these catchments were clearly lower, due to strong retention of atmospheric mercury deposition in these catchments. The current annual input $\mathrm{Hg}$ was 0.8 and 1.8 per mille to the $\mathrm{Hg}$ stored in the upper $90 \mathrm{~cm}$ of the soil in LGS and TSP. Hence, currently most of the atmospherically deposited $\mathrm{Hg}$ is retained in the soil rather than exported to surface water. The long term implication of this, however, is unknown, and in the long term leaching from stored $\mathrm{Hg}$ in forested catchments may occur to a larger extent than today even if the reductions of $\mathrm{Hg}$ emissions from anthropogenic sources to the atmosphere.

\section{Conclusions}

In this study weekly wet-only precipitation $(W P)$, throughfall $(T F)$, stream water $(S W)$, monthly litterfall $(L F)$ and soil profiles were collected to investigate the $\mathrm{Hg}$ fluxes and pools at three subtropical forested catchments (Leigongshan (LGS), Tieshanping (TSP) and Luchongguan $(L C G)$ ) in southwest China. $\mathrm{Hg}$ annual volumeweighted mean concentrations in TF were $36.7 \mathrm{ng} \mathrm{L}^{-1}, 69.7 \mathrm{ng} \mathrm{L}^{-1}$ and $43.6 \mathrm{ng} \mathrm{L}^{-1}$ for $L G S$, TSP and LCG, respectively, which were two times more than those in WP during this study and approximately three times higher than those in $T F$ reported from temperate and boreal forested catchments. The annual total input fluxes of $\mathrm{Hg}$ were $119.5 \mu \mathrm{g} \mathrm{m}^{-2} \mathrm{a}^{-1}$ for LGS and $291.2 \mu \mathrm{g} \mathrm{m}^{-2} \mathrm{a}^{-1}$ for TSP, which were several-fold of those in temperate and boreal forested catchments, suggesting significantly enhanced atmospheric $\mathrm{Hg}$ deposition at subtropical forested catchments in southwest China. Output fluxes of $\mathrm{Hg}$ from stream water were $3.0 \mu \mathrm{g} \mathrm{m}^{-2} \mathrm{a}^{-1}$, $3.5 \mu \mathrm{g} \mathrm{m}^{-2} \mathrm{a}^{-1}$ and $4.5 \mu \mathrm{g} \mathrm{m}^{-2} \mathrm{a}^{-1}$ for LGS, TSP and LCG, respectively, which were comparable to those reported from Europe and North America. The current annual input $\mathrm{Hg}$ only accounted for 0.8 and 1.8 per mille to the $\mathrm{Hg}$ stored in the upper $90 \mathrm{~cm}$ of soil in LGS and TSP. Therefore, for a long term, the large $\mathrm{Hg}$ pools in forest soil may be significant sources for associated lakes even if the reduction of $\mathrm{Hg}$ emission to the atmosphere from the anthropogenic sources in southwest China.

The comparison of $\mathrm{Hg}$ input/output in this study with those reported from temperate and boreal forested catchments showed that the litterfall input of $\mathrm{Hg}$ from the atmosphere was significantly 
higher at TSP and LGS, suggesting that $\mathrm{Hg}$ input via litterfall may play a more important role to the mercury cycling at subtropical forested catchments in China. The ratios of $\mathrm{Hg}$ output from stream water to total input at these catchments were obviously lower than those from temperate and boreal areas although there is a significantly high $\mathrm{Hg}$ input in southwest China. These suggest that subtropical forested catchments are important for retention of atmospheric mercury deposition in southwest China.

\section{Acknowledgements}

This work was supported by Chinese Academy of Sciences (Programs No.RCEES-QN-2007XX and No.KZCX3-SW-443), National Basic Research Program of China (No. 2005CB422206), and Natural Science Foundation of China (No. 40803033). The authors are grateful to Prof. Yujing Mu, Research Center for Eco-Environmental Sciences, Chinese Academy of Sciences, for his valuable comments and suggestions. We also thank our co-workers Dawei Zhao and Liping $\mathrm{Wu}$ in Chongqing Institute of Environmental Science and Monitoring for their assistance in samples collecting.

\section{References}

Bishop, K., Lee, Y., 1997. Catchments as a source of mercury/methylmercury in boreal surface waters. In: Sigel, A., Sigel, H. (Eds.), Mercury and its Effects on Environment and Biology. Metal Ions in Biological Systems, vol. 34. Marcel Dekker, New York, NY, pp. 113-130.

Boening, D., 2000. Ecological effects, transport, and fate of mercury: a general review. Chemosphere 40, 1335-1351.

Chen, B., Wang, X., Lee, F., 2001. Pyrolysis coupled with atomic absorption spectrometry for the determination of mercury in Chinese medicinal materials. Analytica Chimica Acta 447, 161-169.

Choi, H.D., Holsen, T., 2009. Gaseous mercury fluxes from the forest floor of the Adirondacks. Environmental Pollution 157, 592-600.

Copeland, D., Facer, M., Newton, R., Walker, P., 1996. Use of poly(ethylene terephthalate) plastic bottles for the sampling, transportation and storage of potable water prior to mercury determination. Analyst 121, 173-176.

Driscoll, C., Han, Y., Chen, C., Evers, D., Lambert, K., Holsen, T., Kamman, N. Munson, R., 2007. Mercury contamination in forest and freshwater ecosystems in the Northeastern United States. BioScience 57, 17-28.

Esbrí, J., Higueras, P., 2005. Mercury contents in waters from the Valdeazogues Watershed (Almadén, Spain). In: 9th International Mine Water Congress, pp. 155-160.

Fadini, P., Jardim, W., 2000. Storage of natural water samples for total and reactive mercury analysis in PET bottles. Analyst 125, 549-551.

Fatemian, E., Allibone, J., Walker, P., 1999. Use of gold as a routine and long term preservative for mercury in potable water as determined by ICP-MS. Analyst $124,1233-1236$

Feng, X., Tang, S., Shang, L., Yan, H., 2003. Total gaseous mercury in the atmosphere of Guiyang, PR China. The Science of the Total Environment 304, 61-72.

Feng, X., Shang, L., Wang, S., 2004. Temporal variation of total gaseous mercury in the air of Guiyang, China. Geophysical Research 109, D03303, doi:10.1029/ 2003JD00419.

Fischer, R., Rapsomanikis, S., Andreae, M., 1995. Bioaccumulation of methylmercury and transformation of inorganic mercury by macrofungi. Environmental Science and Technology 29, 993-999.

Fitzgerald, W., Engstrom, D., Mason, R., Nater, E., 1998. The case for atmospheric mercury contamination in remote areas. Environmental Science and Technology $32,1-7$

Fleck, J., Grigal, D., Nater, E., 1999. Mercury uptake by trees: an observational experiment. Water, Air and Soil Pollution 115, 513-523.

Fostier, A., Forti, M., Guimarães, J., 2000. Mercury fluxes in a natural forested Amazonian catchment (Serra do Navio, Amapá State, Brazil). Science of the Total Environment 260, 201-211.

Fujieda, M., Kudoh, T., De Cicco, V., De Calvarcho, J., 1997. Hydrological processes at two subtropical forest catchments: the Serra do Mar, São Paulo, Brazil. Journal of Hydrology 196, 26-46.

Galloway, M., Branfireun, B., 2004. Mercury dynamics of a temperate forested wetland. Science of the Total Environment 325, 239-254.

Glass, G., Sorensen, J., 1999. Six-year trend (1990-1995) of wet mercury deposition in the Upper Midwest. U.S.A. Environmental Science and Technology 33, 3303-3312.

Grigal, D., 2002. Inputs and outputs of mercury from terrestrial watersheds: a review. Environmental Review 10, 1-39.

Grigal, D., Kolka, R., Fleck, J., Nater, E., 2000. Mercury budget of an upland-peatland watershed. Biogeochemistry 50, 95-109.

Guentzel, J., Landing, W., Gill, G., Pollman, C., 1995. Atmospheric deposition of mercury in Florida: The FAMS project (1992-1994). Water, Air and Soil Pollution $80,393-402$
Higuerasa, P., Oyarzunb, R., Lillo, J., Sánchez-Hernández, J., Molina, J., 2006. The Almadén district (Spain): anatomy of one of the world's largest Hg-contaminated sites. Science of the Total Environment 356, 112-124.

Huang, R., Zhuang, Z., Tai, Y., Huang, R., Wang, X., Lee, F., 2006. Direct analysis of mercury in traditional Chinese medicines using thermolysis coupled with online atomic absorption spectrometry. Talanta 68, 728-734.

Hultberg, H., Munthe, J., Iverfeldt, Å., 1995. Cycling of methyl mercury and mercuryresponses in the forest root catchment to three years of decreased atmospheric deposition. Water, Air and Soil Pollution 80, 415-424.

Hylander, L., 2001. Global mercury pollution and its expected decrease after a mercury trade ban. Water, Air and Soil Pollution 125, 331-344.

IMPACTS, 2004. Integrated monitoring program on acidification of Chinese terrestrial systems, annual report, results 2003. In: Larssen, T., Tang, D. (Eds.), NIVA report no. 4905-2004, ISBN: 82-577-4594-4.

Johnson, K., Haines, T., 2007. Controls on mercury and methylmercury deposition for two watersheds in Acadia National Park, Maine. Environmental Monitoring and Assessment 126, 55-67.

Kang, W., Trefry, J., Nelsen, T., Wanless, H., 2000. Direct atmospheric inputs versus runoff fluxes of mercury to the lower everglades and Florida Bay. Environmental Science and Technology 34, 4058-4063.

Krabbenhoft, D., Benoit, J., Babiarz, C., Hurley, J., Andren, A., 1995. Mercury cycling in Allequash Creek Watershed, northern Wisconsin. Water, Air and Soil Pollution $80,425-433$.

Larssen, T., Lydersen, E., Tang, D., Gao, J., Liu, H., Duan, L., Seip, H., Mulder, J., Shao, M., Zhang, X., Solberg, S., 2006. Acid rain in China. Environmental Science and Technology 40, 418-425.

Larssen, T., de Wit, H., Wiker, M., Halse, K., 2008. Mercury budget of a small forested boreal catchment in southeast Norway. Science of the Total Environment, doi:10.1016/j.scitotenv.2008.03.013.

Lee, Y., Bishop, K., Munthe, J., 2000. Do concepts about cycling of methylmercury and mercury in boreal catchments stand the test of time? Six years of atmospheric inputs and runoff exports at Svartberget, northern Sweden. Science of the Total Environmental 260, 11-20.

Lindberg, S., 1996. Forests and the global biogeochemical cycle of mercury: the importance of understanding air vegetation exchange processes. In: Baeyens, W., Ebinghaus, R., Vasiliev, O. (Eds.), Global and Regional Mercury Cycles: Sources, Fluxes and Mass Balances. Kluwer Acad. Publishers, Netherlands, pp. 359-380.

Munthe, J., Hultberg, H., Iverfeldt, Å., 1995. Mechanisms of deposition of methylmercury and mercury to coniferous forests. Water, Air and Soil Pollution 80, 363-371.

Munthe, J., Lee, Y., Hultberg, H., Iverfeldt, Å., 1998. Cycling of mercury and methylmercury in the Gårdsjön Catchments. In: Hultberg, H., Skeffington, R. (Eds.), Experimental Reversal of Acid Rain Effects. The Gărdsjön Roof Project. John Wiley and Sons, New York, NY, pp. 261-276.

Munthe, J., Hultberg, H., 2004. Mercury and methylmercury in runoff from a forested catchment concentrations, fluxes, and their response to manipulations. Water, Air and Soil Pollution 4, 607-618.

Nelson, S., Johnson, K., 2007. Mass balances of mercury and nitrogen in burned and unburned forested watersheds at Acadia National Park, Maine, USA. Environmental Monitoring and Assessment 126, 69-80.

Oyarzun, R., Higueras, P., Esbrí, J., Pizarro, J., 2007. Mercury in air and plant specimens in herbaria: a pilot study at the MAF Herbarium in Madrid (Spain). Science of the Total Environment 387, 346-352.

Paraquetti, H., Ayres, G., Almeida, M., Molisani, M., Lacerda, L., 2004. Mercury distribution, speciation and flux in the Sepetiba Bay tributaries, SE Brazil. Water Research 38, 1439-1448.

Peterson, S., Sickle, J., Herlihy, A., Hughes, R., 2007. Mercury concentration in fish from streams and rivers throughout the Western United States. Environmental Science and Technology 41, 58-65.

Porvari, P., Verta, M., Munthe, J., Haapanen, M., 2003. Forestry practices increase mercury and methylmercury output from boreal forest catchments. Environmental Science and Technology 37, 2389-2393.

Rea, A., Lindberg, S., Keeler, G., 2001. Dry deposition and foliar leaching of mercury and selected trace elements in deciduous forest throughfall. Atmospheric Environment 35, 3453-3462.

Rea, A., Linderberg, S., Keeler, G., 2000. Assessment of dry deposition and foliar leaching of $\mathrm{Hg}$ and selected trace elements based on washed foliar and surrogate surfaces. Environmental Science and Technology 34, 2418-2425.

Rodriguez, L., Rincón, J., Asencio, I., Rodríguez, C., 2007. Capability of selected crop plants for shoot mercury accumulation from polluted soils: phytoremediation perspectives. International Journal of Phytoremediation 9, 1-13.

Schwesig, D., Matzner, E., 2000. Pools and fluxes of mercury and methylmercury in two forested catchments in Germany. Science of Total Environmental 260, 213-223.

Sheehan, K., Fernandez, I., 2006. Litterfall mercury in two forested watersheds at Acadia National Park, Maine, USA. Water Air and Soil Pollution 170, 249-265.

Shuvaeva, O., Gustaytis, M., Anoshin, G., 2008. Mercury speciation in environmental solid samples using thermal release technique with atomic absorption detection. Analytica Chimica Acta 621, 148-154.

Siegel, B., Siegel, S., Horsky, S., 1984. Equisetum plants and the cycling of mercury at mount St. Helens'. Environment Science and Technology 18, 179-181.

Silva, G., Jardim, W., Fadini, P., 2006. Elemental gaseous mercury flux at the water/ air interface over the Negro River basin, Amazon, Brazil. Science of the Total Environment 368, 189-198. 
St. Louis, V., Rudd, J., Kelly, C., 2001. Importance of the forest canopy to fluxes of methyl mercury and total mercury to boreal ecosystems. Environmental Science and Technology 35, 3089-3098.

USEPA Innovative Technology Verification Report, 2004. Field measurement technology for mercury in soil and sediment. Ohio Lumex's RA-915+/RP-91C Mercury Analyzer. http://www.epa.gov/ord/SITE/reports/600r03147/600r03147.htm.

Wang, D., He, L., Shi, X., Wei, S., Feng, X., 2006b. Release flux of mercury from different environmental surfaces in Chongqing, China. Chemosphere 64, 1845-1854.

Wang, Y., Solberg, S., Yu, P., Myking, T., Vogt, R., Du, S., 2007b. Assessments of tree crown condition of two Masson pine forests in the acid rain region in south China. Forest Ecology and Management 242, 530-540.

Wang, Z., Chen, Z., Duan, N., Zhang, X., 2007a. Gaseous elemental mercury concentration in atmosphere at urban and remote sites in China. Journal of Environmental Sciences 19, 176-180.
Wang, Z., Zhang, X., Chen, Z., Zhang, Y., 2006a. Mercury concentrations in sizefractionated airborne particles at urban and suburban sites in Beijing, China. Atmospheric Environment 40, 2194-2201.

Wang, Y., Liang, L., Shi, J., Jiang, G., 2005. Chemometrics methods for the investigation of methylmercury and total mercury contamination in mollusks samples collected from coastal sites along the Chinese Bohai Sea. Environmental Pollution 135, 457-467.

Wei, X., Liu, S., Zhou, G., Wang, C., 2005. Hydrological processes in major types of Chinese forest. Hydrological Processes 19, 63-75.

Won, J., Park, J., Lee, T., 2007. Mercury emissions from automobiles using gasoline, diesel, and LPG. Atmospheric Environment 41, 7547-7552.

Wu, Y., Wang, S., Streets, D., Hao, J., Chan, M., Jiang, J., 2006. Trends in anthropogenic mercury emissions in China from 1995 to 2003. Environmental Science and Technology 40, 5312-5318. 